\title{
The Administration of ICT Utilization for Teaching-Learning in Basic Elementary School in Thailand
}

\author{
Sakoolrat Kamothamas
}

\begin{abstract}
This research aimed: 1) to study the opinions and correlation of the school administration to information technology staffs of ICT Utilization for Teaching-Learning in Basic Elementary School. 2) to compare opinions of the school administrators and information technology staffs for teaching-learning in basic elementary school in Thailand divided by positions, size, and location. The samples in this research included 191 school administrators and 191 information technology staffs in basic elementary school in Thailand. The major instruments were questionnaires. The Statistical data were used to analyze by percentage $(\%)$, mean $(\overline{\mathbf{X}})$, standard deviation. (S.D.), t-test, F-test and multiple correlation (The spearman rank difference method).

The results of the research indicated that there were 164 deputy directors in an overall high level and 187 information technology staffs. Most school administrators and information technology staffs were in small school lower than 499 students. The study of opinion of school administrators and information technology staffs of ICT Utilization for Teaching-Learning in Basic Elementary School, generally agreed at the moderate level of utilizing technology for the system. The correlation of the school administration to information technology staffs about ICT Utilization for Teaching-Learning had not correlated statistically at $\mathbf{. 0 1}$ level. The position, location, and size of school were different statistically significant at .01 level.
\end{abstract}

Index Terms-ICT utilization, teaching-learning, basic elementary school.

\section{INTRODUCTION}

The impact of information and communications technology (ICT) on economic performance has been an interesting issue in economics including educational area. There are at least three key points that can be learnt from the previous literatures regarding ICT and country's economic performance. First, more developed countries are expected to benefit greater than less developed countries. Second, the impact of ICT will depend on the intensity of ICT utilization. Third, the size and structure of ICT sector of country's economy does matter. The ultimate goal of the current Minister of Education's policies is to increase Thai students' performance and achievements in key subject areas measured in the Program for International Student Assessment, or PISA. For this purpose, the following ICT policies will be implemented and accelerate the use of ICTs, including tablets, as tools to develop teaching pedagogy, learning content,

Manuscript received December 30, 2014; revised March 12, 2015.

Sakoolrat Kamothamas is the the director of Master Degree of Education Department, Faculty of Education, the Eastern University of Management and Technology, Thailand (e-mail: dr.sakoolrat22@gmail.com). learning standards, evaluation and assessment standards, and to promote lifelong learning Thai society [1].

The second ICT master plan (2009-2013) or Thailand ICT Master Plan Issue II follows the IT 2010 plan and the first ICT master plan (2002-2006), updated with new policies to keep up with the changes in technology, economics and society. The plan is both a tool and an opportunity for increasing the competitiveness of Thailand (Ministry of ICT, 2009). During this second ICT master plan, six major strategies were identified. They were 1) Increasing ICT human resource in both quality and quantity 2) developing good governance frameworks for national ICT governance 3) continuing to develop basic infrastructure in order to minimize digital divide and developing high speed ICT networks 4) achieving ICT management governance 5) supporting manufacturing, empowering businesses and the ICT industry in order to create economic value, leverage industry competitiveness competence, and generate more income and 6) increasing smart and skillful ICT workforce and utilizing ICT for sustainable growth of the nation (Ministry of ICT, 2009). In addition, the objective was on achieving what have not been achieved under Thailand ICT Master Plan Issue I. The points addressed by this plan are closing digital divide by the use of new technology such as last mile access and providing an access for disabilities and needy people.

TABLE I: BRIEF HISTORY OF ICT FOR EDUCATION IN THAILAND

\begin{tabular}{ll} 
Period & ICT For Education Master Plan (2007-2011) \\
\hline Major Issues & - Smart Thais with Information literacy \\
Key Policies & - Educational human resource and \\
& professional development \\
& - ICT Info. Infra. \\
& - Digital Content in every subject areas \\
Teaching-Learning & - Integrating ICT into teaching and learning \\
& - Blended Learning \\
Successes & - Quantum Jump Policy/Strategies and budget \\
& to acquire hw, sw and digital contect \\
Unfinished Projects & Systematic/Holistic approach to restructure \\
& the entire system
\end{tabular}

The current phase is during the ICT for Education Master Plan 2007-2011. The implementation of ICT for Education Master Plan was delayed due to a delay of endorsing the National Master Plan 2009-2013. This was again due to the internal political turmoil. Its goal was to create Smart Thais with Information Literacy. Some of the focuses were (again) on educational human resource and professional development, an investment in ICT Information Infrastructure and creation of digital content in every subject 
areas. Regarding teaching and learning, the challenge has moved to integrating ICT into teaching and learning in Thai classrooms as well as using ICT as a part of their blended learning. Despite the fact that this plan has just been endorsed one of the things worth mentioning here is the success on instant policy/ strategies and budget to acquire hardware, software and digital content (and perhaps networks) for every school under the national Strong Thai or "Thai Kem Kang" (TKK) project.

However, the two most important issues that need to be seriously taken into consideration are 1) to implement a systematic / holistic approach to restructure the entire educational system with the use of ICT and at the same time 2) to vaccinate Thai youths or young learners to have strong netiquette to prevent an inappropriate use of the Internet.

Equity: The Current Status of Information Infrastructure and Digital Divide Issues. Overall Thailand ICT infrastructure is growing at a steady pace [2], [3].

However, quality infrastructure is not yet sufficient to serve the needs of the population of over 70 million. Still about $1 \%$ of all households in Thailand lacked electricity (most are in the southern part). Level of ICT use for Thais is at $20.3 \%$. ICT mostly used are still TVs and radios (93\% and $63.3 \%$ ). Currently, there are 10.89 basic phone numbers per 100 people. Regarding the access to Mobile phones, like several countries in Asia, no digital divide is found in Thailand with $68 \%$ in BKK and $55 \%$ in rural areas.

However, for the access to computer, the percentage for computer use is at $26.8 \%$. Recent data from the Ministry of ICT showed that over $30 \%$ of the population in cities in all regions used a computer, with the highest percentage in Bangkok (40\%). The ratio of the number of computers to the number of students in schools under the OBEC is now 1:40 The numbers of users of mobile phones and computers in Thailand stand at 28.29 and 16.04, respectively. Regarding the internet access, our internet bandwidth expansion is growing steadily since 2003. Recent data on the Internet Usage in Asia showed that Thailand ranked 11th among Asian countries in terms of the number of Internet users . Thailand started well in 2000 with 2.3 million internet users.

However, now Thailand has around 13.4 million users, which accounts for $20.3 \%$ of the whole population with the growth rate of $48.33 \%$. Among these, 1.2 million are high speed internet users and more than 600,000 are broadband internet users. This limited progress was mainly due to the economic recession that caused the decline in government investment in ICT and the internal political turmoil that caused the constant changes of government [4].

\section{PURPOSES OF THE STUdY}

The research main objectives were (1) to study the opinions and correlation of the school administration and information technology staffs of ICT Utilization for Teaching-Learning in Basic Elementary School (2) to compare opinions of the school administrators and information technology staffs divided by position, size, and location of school with ICT utilization for teaching-learning in basic elementary school in Thailand.

\section{Statement of Problem}

The necessity of transformation in education shall be and schools in the twenty-first century are clear all over. Change in schools necessitates relocation and change of philosophy of public education. And it is the starting point of such changes in terms of having insight. The future learning environment to create sustainable changes in education shall be necessary.

Today, ICT as a component and complements the educational system is known around the world, the role of department heads and professors. ICT in increasing the quality of teaching and learning and the rest of the process are undeniable. With a diverse and complex society that the process for the preparation of independent thinkers as teenagers, more productive citizens and leaders of the future and more complex nature of the educational experiences of students. change, learning, teaching and assessment, significant implications for the efficiency of all changed the way they have been training [2]. Despite the increasing development of the smart schools and accelerating developing countries move towards a small collection in the field of research that challenges the development of these schools has taken place [5]. We are today in the midst of the powerful waves of the revolution have information to be allied with the foot of the schools require students to go ahead, the philosophical society of Norwegian should change in the assessment of the community perception of training shall be the inventions and technology with deep effects., the central core of this transformation is the necessary instruments to create educational professionals on the tour puts the information on schools if the intellectual skills and further up the kid and use tools such as computers, in the integration of teaching and learning methods in teaching English as well as the expectations of teachers, administrators, and on the other as a result of these changes will be GON physical structure and internal organization of schools will change [6].

The main concerns of the present study are on the opinions and correlation of the school administration and information technology staffs of ICT Utilization for Teaching-Learning.

\section{DEFINITION OF TERM.}

For the purpose of this study, the terms were defined as following:

The administration is defined as an organization in an entity, which generates ideas, provides services or produces tangible products from appropriate inputs using resources.

ICT is defined as often used as an extended synonym for process information technology (IT), but is a more specific term that stresses the role of unified communications and the integration of telecommunications (telephone lines and wireless signals), computers as well as necessary enterprise software, middleware, storage, and audio-visual systems, which enable users to access, store, transmit, and manipulate information for implementing student life skills.

Utilization is defined as the primary method by which asset performance is measured are educational success determined. It is are output of overall processes.

Basic elementary school is defined as the main point of 
delivery of primary education in the Thailand, for children between the ages of 5-6 and 10-12 years old coming between Pre-Kindergarten and elementary education.

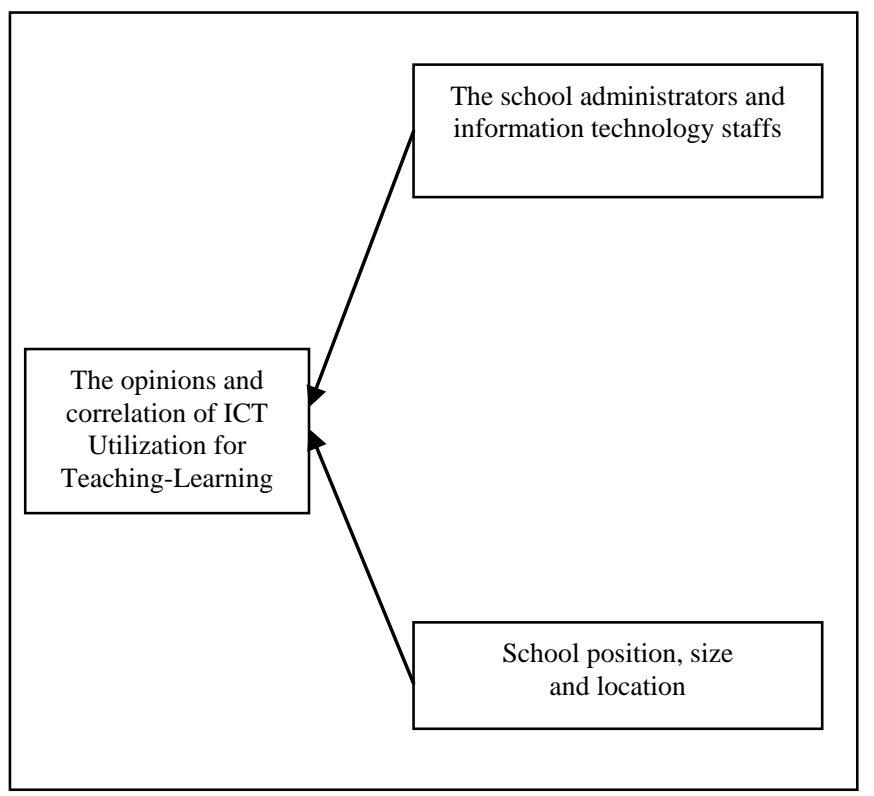

Fig. 1. The conceptual framework.

\section{SCOPE OF STUDY}

Population of study are school administrators and information technology staffs in primary school under the Office of the Basic Education Commission of Thailand which 62,386 persons from primary school. The samples in this research included 191 school administrators and 191 information technology staffs in basic elementary school, specifying sample size by Krejcie and Morgan table. The major instruments were questionnaires. The Statistical data were used to analyzed percentage $(\%)$, mean $(\bar{x})$, standard deviation. (S.D.), t-test, F-test and multiple correlation (The spearman rank difference method).

\section{INSTRUMENTS}

The instruments used in this study were 6 parts of questionnaires developed by the researcher. The subjects provided their responses on the questionnaires forms. The questionnaires were verified for content validity by a panel of five experts from the department of Basic Elementary at the Ministry of Education, Thailand using content validity ratio (CVR) and validated for reliability using alpha coefficients. Thirty subjects of each sample group were used for try-out for each questionnaire. The Statistical Package for the Social Science for Window (SPSS/FW) was used for computing the reliability coefficient of the questionnaires. Chronbach's Alpha $(\alpha)$ was .92. Internal consistency reliabilities were established based on this study.

The data were collected from School administrators and information technology staffs in which school list name by Ministry of Education, Thailand via a mail survey to participants. Data were collected through a mail survey included the authorized letter by The Eastern University of Management and Technology. Surveys were mailed to all
School administrators and information technology staffs in Thailand. The survey included directions about how to complete the instrument and where and when to return the instrument, a questionnaire about the opinions and correlation of ICT Utilization for Teaching-Learning in Basic Elementary School. A stamped envelope with the researcher name and address was included. Participants were asked to return the survey within two weeks of receiving the instrument. A follow-up was mailed four weeks after the initial mailing with the same instructions. It was estimated that approximately 191 school administrators and 191 information technology staffs responses would be returned.

\section{RESULTS}

Quantitative mean score of each item was classified to match with qualitative values as in Table II.

TABLE II: ICT UTILIZATION FOR TEACHING-LEARNING

\begin{tabular}{lccc}
\hline \hline Variable & $\bar{X}$ & S.D. & Result \\
\hline Academic Planning & 3.06 & 0.72 & Moderate \\
Academic Management & 3.19 & 0.64 & Moderate \\
Academic Development & 3.41 & 0.60 & High level \\
Academic Evaluation & 3.35 & 0.53 & High level \\
Academic Assessment & 3.17 & 0.85 & Moderate \\
ICT Teaching \&Learning & 3.31 & 0.71 & Moderate \\
\multicolumn{1}{c}{ SUM } & 3.25 & 0.67 & Moderate \\
\hline \hline
\end{tabular}

TABLE III: SCHOOL ADMINISTRATORS AND INFORMATION TECHNOLOGY

\begin{tabular}{lccc}
\multicolumn{4}{c}{ STAFFS } \\
Variable & $\bar{X}$ & S.D. & Result \\
\hline HR Resource Planning & 3.13 & 0.84 & High level \\
Operation Plan & 2.87 & 1.12 & Moderate \\
School size & 3.10 & 0.89 & High level \\
Teaching Material & 3.05 & 1.04 & High level \\
Budget Planning & 2.89 & 1.07 & Moderate \\
Location & 3.03 & 0.97 & High level \\
\multicolumn{1}{c}{ SUM } & 3.01 & 0.98 & High level \\
\hline \hline
\end{tabular}

TABLE IV: ICT UTILIZATION

\begin{tabular}{lcc}
\hline \multicolumn{1}{c}{ Variable } & $\begin{array}{c}\text { Colinearrity } \\
\text { Tolerance }\end{array}$ & $\begin{array}{c}\text { Statistic } \\
\text { VIF }\end{array}$ \\
\cline { 1 - 1 } HR Resource Planning & .857 & 1.166 \\
Operation Plan & .834 & 1.240 \\
\cline { 1 - 1 } School size & .627 & 1.731 \\
\cline { 1 - 1 } Teaching Material & .621 & 1.761 \\
\cline { 1 - 1 } Budget Planning & .595 & 1.880 \\
\hline \hline
\end{tabular}

The Tolerance and Variance Inflation Factor are presented in Table IV. There were considered results show all the VIF values fall below 5 , indicating the low multicollinearity.

The result of multiple regression by Enter method, the multiple correlation coefficient between ICT Utilization. A regression $R^{2}$ and significant by F-test

From Table V, the multiple correlation coefficient were .867 which were statistically significant at .01 level. All factors explained variance at 75.10 percentage.

The beta weight of the factors which contributed to trend of ICT Utilization by t-test. 
TABLE V: THE MULTIPLE CORRELATION COEFFICIENT BETWEEN ICT UTILIZATION

\begin{tabular}{clcccc}
\hline \hline Model & & $d f$ & $\begin{array}{l}\text { Mean } \\
\text { Square }\end{array}$ & $F$ & Sig \\
\hline 1 & Regression & 6 & 2.678 & 10.854 & $.000(a)$ \\
& Residual & 151 & .248 & & \\
& Total & 154 & & & \\
\hline \hline
\end{tabular}

a: Predictors: (Constant)

$b$ : Dependent variable: ICT utilization.

\begin{tabular}{ccccc}
\hline \hline Model & $R$ & $R$ & Adjust & $\begin{array}{c}\text { Std. Error of } \\
\text { the Estimate }\end{array}$ \\
\hline
\end{tabular}

$\begin{array}{lllll}1 & .867(a) & .751 & .862 & .508\end{array}$

a: Predictors: (Constant)

TABLE VI: THE BETA WEIGHT OF THE FACTORS WHICH CONTRIBUTED TO ICT UTILIZATION

\begin{tabular}{lccccc}
\hline \hline \multicolumn{1}{c}{ Variable factor } & $\beta$ & $b$ & SE & $T$ & $p$ \\
\hline HR Resource & .379 & .166 & .086 & $1.161^{* *}$ & .00 \\
Planning & .340 & .143 & .071 & $.565^{* * *}$ & .00 \\
Operation Plan & .213 & .123 & .042 & $1.432^{* *}$ & .00 \\
School size & .169 & .116 & .059 & $1.461^{* *}$ & .00 \\
Teaching Material & .239 & .139 & .039 & $.430^{* *}$ & .00 \\
Budget Planning & .312 & .148 & .068 & $.455^{* *}$ & .00 \\
Location & & & & & \\
\hline
\end{tabular}

** Significant at the 0.01 level.

\section{CONCLUSIONS}

The following conclusions are based on the finding of this study.

Part 1: The research indicated that 164 deputy directors in an overall high level and 187 information technology staffs. Most school administrators and information technology staffs were in small school under 499 students.

Part 2: The opinion of school administrators and information technology staffs of ICT Utilization for Teaching-Learning in Basic Elementary School, generally agreed at the moderate level. The planning/job/project and information technology development goals generally agreed at the high level. And resource or material allocated to proceed as computer hardware, software was at the low level. The study of opinion school administrators and information technology staffs of productivity generally falled Citing from problems and suggestions, most samples complained about lacking of ICT personnels and needed to be trained in ICT teaching learning utilization at the high level. And ICT school data were applied to school situations. The study of opinion school administrators and information technology staffs of ICT Utilization application generally agreed at the moderate level. ICT school planning and decision making were at the low level.

Part 3: The opinion of school administrators and information technology staffs of learning process generally agreed at the moderate level. In developing thinking and management was at the high level as learning process with project. The Benjamin Bloom questions were at the low level. The learning process by experience found that generally agreed at the moderate level. The learning process by teaching material at high level and learning process by multiple integration was at the low level. The study of opinion school administrators and information technology staffs of Information Technology Resources found that generally agreed at the moderate level. And self-development was at the low level.

Part 4: The correlation of the school administration to information technology staffs about ICT Utilization for Teaching-Learning had not correlated statistically at .01 level. The position, location, and size of school were different statistically at .01 level.

\section{DISCUSSION}

Considering from the percentage of the lower level of correlation of ICT utilization, the results of this research can be assumed that ICT utilization in school is not concentrated in teaching learning process for the quality of the students. According to the condition of child-centered learning in primary school was rated at the moderate level, however, when classified according to the school size and location, it was found to be significantly different $(p<.05)$. The problem of child-centered learning was rated at the moderate level and when classified according to school size, they were found to be different in all aspects. The differentiation of school and location were found to be significantly different $(p<.05)$ along with researcher of Pavena Modrakee [7]-[10].

Also, the results confirmed to W. Attasit, who found that the teacher and administrators perceived the state of the overall utilization of information technology and communication to be at moderate level. When individual aspects were taken into account, it was found that the performance on the utilization on the information was at a high level, while the utilization of internet and communication and the use of computer in teaching and learning were at a moderate and low level respectively [11].

\section{RECOMMENDATIONS}

1) Should study in ICT utilization in education precisely.

2) Should investigate the conditions of problems about how to use information technology management program in depth to develop model for information technology in school wisely.

3) Should study how to use technology for learning achievement of students all over the country.

4) Should study information technology model for compatibility for management in primary school under Office of the Basic Education Commission of Thailand

5) Supply enough ICT teachers immediately.

\section{REFERENCES}

[1] I. Tony, International Economics and Economic Policy 11.1-2, pp. 97-114, Feb. 2014

[2] B. P. Shahrakipor, The Advent of the New Millennium, Pedagogy Learn Cognitive Publications, Tehran, p. 341, 2003.

[3] ICT for Education Master Plan 2007-2011, Ministry of ICT, Bangkok: Ministry of ICT, 2009.

[4] The Ministry of Education Thursday, Smart Schools, Executive guidance roadmap, 160 schools page.

[5] C. Mahmoudi, S. Nalchigar, M. Ebrahimi, and S. Sadeghi, "Reviews of smart schools in the country's development challenges," Journal of Educational Innovation, vol. 27, pp. 78-68, 2006. 
[6] S. H. Zoufan, New Technology Application in Train, Tehran: the publishing side, p. 295, 2006.

[7] I. P. Shokor and V. N. Far, "Academic achievement when creating smart schools using genetic algorithm," in Proc. the 5th National Conference and the 2nd International Conference on Learning and Electro-Nik, Amirkabir University of Technology, Tehran, Iran, 2010.

[8] T. Laohajaratsang, "E-learning development readiness of Thailand's higher educational institutes," in Proc. the International Conference on e-Learning, e-Learn, Las Vegas, USA, November, 2008.

[9] Survey Research Report on the Evaluation of ICT for Education, Bangkok: Ministry of Education, 2009.

[10] M. Pavana, "The investigation of the conditions, problem and strategies to promote child-centered learning in primary school under the office of private education commission region 12," M.Ed. thesis, Dept. Education., Burapha Univ., Thailand, 2002.

[11] W. Attasit, "The state and problem of the utilization of information technology and communication in school management in Ubon Ratchathani educational service area 4," M.Ed. thesis, Dept. Education. Ubon Ratchathani Rajabhat Univ., Ubon Ratchathani, Thailand, 2007.

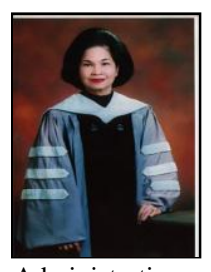

Sakoolrat Kamothamas is a lecturer at Department of Education, Graduate School, the Eastern University of Management and Technology, Thailand. She graduated with $\mathrm{Ph} . \mathrm{D}$. in business administration, University of Atlanta, U.S.A., Ed.D Education, Columbia University, U.S.A., Ed.M Education, Columbia University, U.S.A. M.A Education Administration, Northeast Missouri State University, Kirksville, U.S.A. M.Ed Education Administration, University of Missouri, U.S.A., M.Ed Education, Srinakharinwirot University, Thailand, B.Ed Education, Srinakharinwirot University, Thailand.

She has experience in many positions such as director of master of education program, consultant of International Education Committee University of Atlanta and consultant of Research and Standard Development Institute. Presently, She is in charge of dean of education and director of master of education degree level at the Eastern University of Management and Technology, Thailand. 